\title{
Nesting frogs - the breeding biology of Indirana cf. tysoni in the Western Ghats, India
}

\author{
MADHUSHRI MUDKE ${ }^{1,2,3 *}$ \& BENJAMIN TAPLEY ${ }^{4}$ \\ ${ }^{1}$ Suri Sehgal Center for Biodiversity and Conservation, Ashoka Trust for Research in Ecology and the Environment (ATREE), \\ Royal Enclave, Jakkur Post, Bangalore 560064, India \\ ${ }^{2}$ Manipal Academy of Higher Education, Manipal 576104, India \\ ${ }^{3}$ EDGE of Existence Programme, Zoological Society of London, Regent's Park, London, NW1 4RY, UK \\ ${ }^{4}$ Zoological Society of London, Regent's Park, London, NW1 4RY, UK \\ *Corresponding author e-mail: madhushri.m@atree.org
}

\begin{abstract}
Frogs of the genus Indirana are endemic to India. Previous research on these frogs has focussed on taxonomy and systematics but their behaviour remains largely understudied. Here we report the breeding behaviour of Indirana cf. tysoni, including nest building, male to male combat, inguinal amplexus, egg clutch guarding, tadpoles and polymorphism. We also analyse advertisement calls and present a comparative analysis with previously published data. Lastly, we discuss the need to study these breeding behaviours in-depth in order to help frame appropriate conservation plans.
\end{abstract}

\section{INTRODUCTION}

$T_{\text {to }}^{\text {he }}$ he frog family Ranixalidae Dubois 1987 is endemic to India. It comprises two genera; Indirana Laurent, 1986 (14 spp) and Walkerana Dahanurkar, Modak, Krutha, Nameer, Padhye, and Molur, 2016 (4 spp). Ranixalid frogs are of an ancient lineage that has persisted due to the longterm climatic stability of the Western Ghats (Roelants et al., 2004). Many Indirana are known to live close to human modified areas in low to mid elevation, 66-1508 $\mathrm{m}$ a.s.l., in mixed forest types (Garg \& Biju, 2016; Mudke et al., 2020). Previous research on Indirana has focused on taxonomy and systematics (e.g. Dahanukar et al., 2016) but much of the behaviour and natural history of the genus remains a mystery (Nair et al., 2012; Dahanukar et al., 2016; Garg \& Biju, 2016).

There are relatively few published descriptions of the calls made by Indirana species (Kadadevaru et al., 2000; Kuramoto \& Joshy, 2001; Kuramoto \& Dubois, 2009; Modak et al., 2016) which are known to have more than one call type (Gaitonde \& Giri, 2014; Modak et al., 2016). Indirana exhibit sexual size dimorphism with females larger than males (Gopalan et al., 2012). Primitive inguinal amplexus within the members of this genus has been documented by Gaitonde \& Giri, (2014). Indirana lay terrestrial eggs which may be attached to tree bark or within rocky crevices (Sekar, 1992; Tapley et al., 2011; Nair et al., 2012; Gaitonde \& Giri, 2014; Mudke \& Thunga, 2020). These eggs hatch into semi-terrestrial tadpoles that develop on moist rocky surfaces (Kuramoto \& Joshy, 2002; Veeranagoudar et al., 2009; Gopalan et al., 2012). There are also reports of nest building in Indirana duboisi (Mudke \& Thunga, 2020) and possible egg clutch guarding in Indirana cf. semipalmata (Tapley et al., 2011).

In this study, we report novel aspects of the breeding biology and describe the advertisement call of Indirana cf. tysoni Dahanukar, Modak, Krutha, Nameer, Padhye and Molur 2016. The species is restricted to the southern Western Ghats of India and is currently known from Ranipuram in Kerala and from Chikmagalur district (Charmadi Ghats) and Kodagu district (Bhagamandala, Coorg, Madikeri and Thalakaveri) in Karnataka (Dahanukar et al., 2016; Garg \& Biju, 2016). The species has not been assessed by the International Union of Conservation of Nature (IUCN).

\section{MATERIALS AND METHODS}

All individuals in this study were assigned to $I$. tysoni on the basis of external morphology as this species can be distinguished from its potentially sympatric congeners by the tympanum diameter being visibly smaller than eye diameter (Dahanukar et al., 2016; Garg \& Biju, 2016). Our study location was only $0.24 \mathrm{~km}$ away from a published record $\left(12^{\circ}\right.$ $13^{\prime} 12.36^{\prime \prime} \mathrm{N}$ and $75^{\circ} 39^{\prime} 20.52^{\prime \prime} \mathrm{E}$ ) of I. tysoni (see Garg \& Biju, 2016) where species identity was confirmed with molecular data.

Our study was undertaken in Yevakapadi hamlet, Kodagu District, Karnataka State, India $\left(12^{\circ} 13^{\prime} 7.32^{\prime \prime} \mathrm{N}\right.$ and $75^{\circ}$ 39'26.28" E, $1157 \mathrm{~m}$ a.s.l.). A single person (MM) made all the observations in this study. Observations were made for 5 hours daily from 19:30 to 00:30 h from the 24th to 26th August 2017 and from the 6th to 9th July 2018. All the observations were made under red light as we have observed that frogs continue to exhibit behaviours such as calling in red torchlight whereas such behaviours were interrupted when frogs were illuminated with white light. White light was used only for photographs. Videos and calls were recorded at a distance of approximately $30 \mathrm{~cm}$ from the frogs (Crump, 2010; ARG-UK, 2008) using an iPhone SE A1723 in-built camera and voice recording app. The ambient temperature and humidity were recorded using a Brunton ADC Pro handheld weather station but only in the year 2018, this equipment was not available in 2017. Snout-vent lengths were measured using a ruler in the field in July 2018 for one male and one female at our 

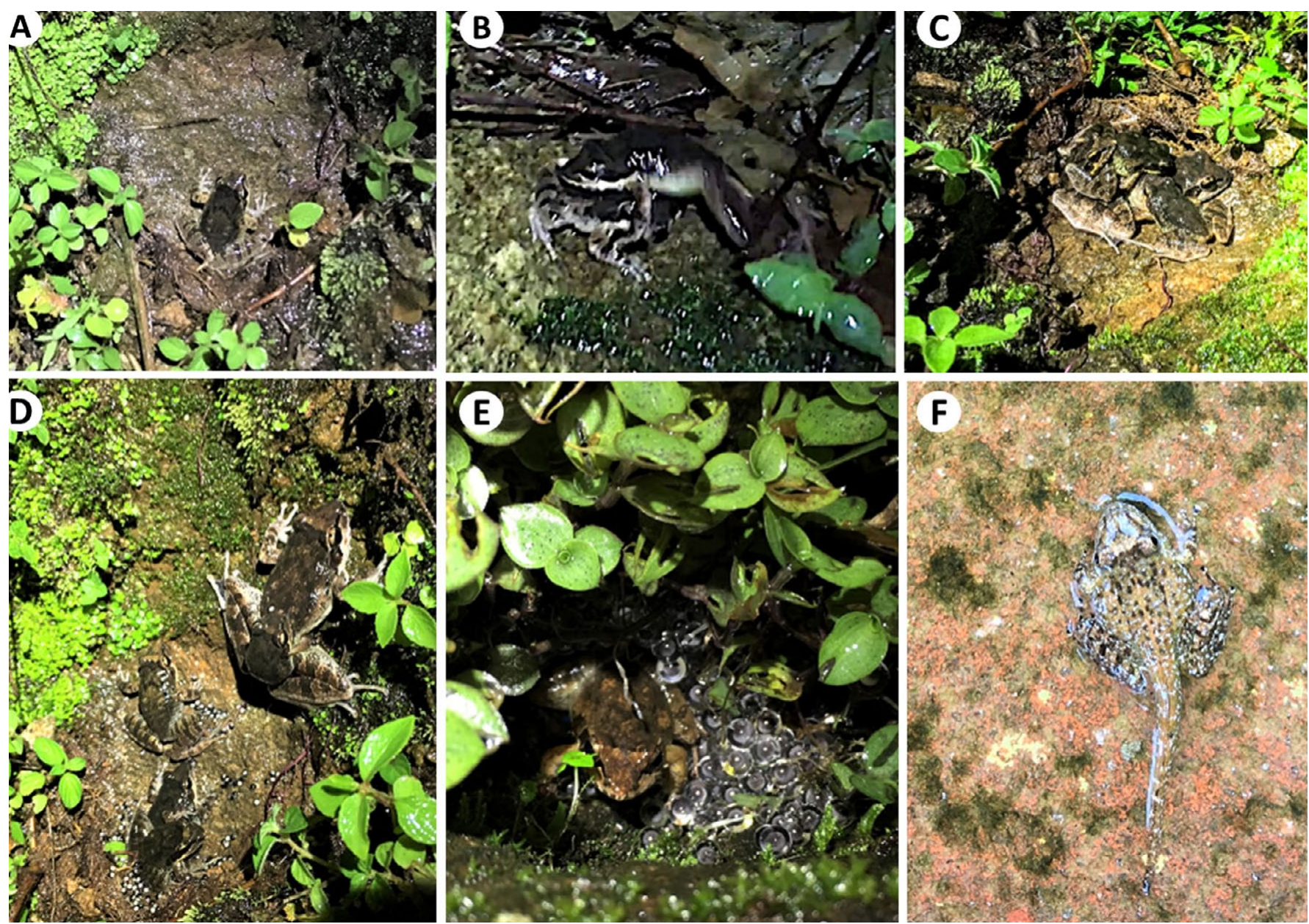

Figure 1. The breeding behaviour of Indirana cf. tysoni at a single nest site- A. Male at a cleared nest site, B. Male to male combat in the form of wrestling between two males, $\mathbf{C}$. At least three males trying to mount the female at the same time at the nest site, D. The primary pair in inguinal amplexus with other males appearing to fertilise eggs at the nest site, E. Male attending to the eggs at a different nest site, F. A semiterrestrial tadpole on a wet rock surface at the study site

study site. Only two frogs were measured as the process of measuring was deemed disruptive to the process of observing natural behaviours. The number of eggs within an egg clutch was counted from photographs that were taken of six separate egg clutches; this egg counting method was chosen to minimise disturbance. A single clutch was classified as all the eggs that were visible in a single 'nest'. The number of males attending eggs, the presence of markings and colour of the dorsum (to track individual frogs over time) and breeding behaviours were noted opportunistically in field.

Two advertisement calls were recorded and analysed with Raven Pro@ v.1.5 software (Center for Conservation Bioacoustics, 2014). The audiospectrograms were calculated with fast Fourier transform (FFT) of 512 points, $50 \%$ overlap using Hanning windows. Call groups and pulses definitions follow Duellman (1970). An 'advertisement call' is defined here as a single vocalisation produced during one expiration following Brown \& Richards (2008). Temporal and spectral parameters of calls were measured as given by Cocroft \& Ryan (1995). We measured the call duration (ms), intercall interval (ms), call repetition rate (calls/s), number of pulses per call, and dominant frequency $(\mathrm{kHz})$ following the the callcentered terminology of of Köhler et al. (2017). Comparative advertisement call records for Indirana species were taken from the published literature describing the advertisement calls of four species; Indirana cf. beddomii (Kadadevaru et al., 2000), I. semipalmata (Kuramoto \& Joshy, 2001), I. gundia (Kuramoto \& Dubois, 2009) and I. chiravasi (Modak et al., 2016). Since some of the published studies did not report all call parameters in the same way, we were unable to provide a consistent comparison of calls between all species.

\section{RESULTS}

We confirmed sexes by observing sexual size dimorphism as seen in the field (Fig. 1D), male ( $S V L=21 \mathrm{~mm}$ ) and female $(\mathrm{SVL}=45 \mathrm{~mm})$, and by observing the smallest individual vocalising (there are no published records of female ranixalid frogs vocalising). To view some details of frog behaviour and micro-habitat view our video (BHS video, 2021).

\section{Nest building}

A 'nest', in this context, is defined as a site for oviposition associated with habitat alteration by the species, nest construction and nest attendance (Peter \& Reid, 2010). Indirana cf. tysoni males were observed clearing a site using their hind limbs. The males cleared space on a mound consisting of ephemeral vegetation, mosses, algae and moist 
rocks. We observed males clearing a space of debris, leaves, vegetation, gravel, mud, algae and mosses to prepare the site for oviposition since the males used this cleared space to make advertisement calls and for amplexus. In one instance the male also used forelimbs to clear required space. A total of three such nest building events were recorded during our night time observations (6th July 2018; 19:40 h; 7th July 2018; 20:05 $\mathrm{h}$ and 22:45 h). Only once was nest building observed (22:45 - 22:55 h) followed by subsequent amplexus and oviposition (23:15 - 00:25 h), on 7th - 8th July 2018 (Fig.1 $A \& D)$. Other characteristics typical of nesting sites included the continuous dripping of water into the cleared space with an outflow.

\section{Male to male combat}

One instance of male to male combat was recorded at the nesting site depicted in Figure 1. After the male frog had constructed a nest (7th July 2018; 22:45 - 22:55 h) he began calling from the edge of it (hereon nest constructing males are termed 'primary males'). At the time, no eggs were seen in the nest. At 22:59 $\mathrm{h}$ another male (intruder) approached the primary male. Both the males called frequently whilst facing each other. Within the next five minutes, two more intruding males approached the nest. All were croaking at each other whilst moving closer to the nesting site. Thereafter male to male combat ensued where males kicked with their hind limbs, wrestled with their forelimbs and jumped over each other in order to take their position on the nesting site (Fig. 1B). At least five males were seen at the single nest site, four minutes before a female approached the site. The male to male combat lasted for a total of 11 minutes from when the intruder males entered the nesting site to the primary male engaging in inguinal amplexus with a female. We closely observed the primary male who had built the nest and he remained closest to the cleared site within the nest despite the presence the intruder males. All the males remained nearby, almost in sight of the observer, when the female approached the nest site.

\section{Amplexus and oviposition}

The female approached the nest site described above at 23:14 h. At 23:15 h, the primary male and the female were in inguinal amplexus while other males attempted amplexus with her (Fig. 1C). Only the primary male engaged in amplexus and did so for a total of 71 minutes before separation (Fig. 1D). Whilst the pair was amplectant, several intruder males tried to mount the female but were unsuccessful. We did not observe any attempts by the other males to dislodge or disrupt the amplectant male. All the males remained in the nest site until the female had laid eggs (Fig. 1D). The female positioned herself just above the nest, and deposited the eggs into it. Immediately after oviposition (00:25 h), all the intruder males moved from the amplectant pair towards the egg clutch and gathered on and around it. Multiple males appeared to be fertilising the eggs (Fig. 1D) as they all deliberately positioned their cloaca directly above the eggs. The pair remained in amplexus for a further 30 seconds after the female had laid her eggs. She then moved out of the nesting site $(00: 27 \mathrm{~h})$ and the primary male moved towards the eggs. The following morning, the primary male, identified by his distinct dorsal patterns, was seen guarding the egg clutch. Intruder males had departed from the site.

\section{Egg clutch attendance}

Egg attendance, in this case, is defined as, 'a parent remaining at the egg mass at a fixed location' (Wells, 2007). Individual males were observed attending eight egg clutches among the 11 that we assessed over the study period. Adult males were seen sitting approximately 2 to $3 \mathrm{~cm}$ away from the deposited egg clutch (Fig. 1E). In two instances the males were seen sitting within the egg clutch with eggs on their dorsum. Adult male frogs remained at the nest site for at least three days but it was not confirmed that they remained with the eggs until they hatched as this would have required observations beyond the study period.

\section{Clutch size}

Out of the 11 egg clutches assessed in this study, we made egg count estimates for only six egg clutches since photographs of the five other clutches were discounted due to poor quality. The mean egg count was 200.3 (range $94-306, \mathrm{~N}=6$ ) (Fig. 1E).

\section{Tadpoles}

During the field survey, we recorded semi-terrestrial tadpoles on almost all wet rocks at the study site on 25th August 2017 and 7th July 2018. Tadpoles were seen at three different developmental stages; stage of $17-21$, stage of $26-40$ and almost a full grown froglet with tail (stage $>41$ ) as per Gosner (1960) (Fig. 1F).

\section{Variation in dorsal colour}

Indirana cf. tysoni is polymorphic; we recorded three different types of dorsal coloration and pattern among 15 males. A single male was seen with bright ochre yellow snout and dorsal midline, another was seen with a light tan dorsum (Figs. 2A \& B); 13 males were seen with a dark, unmarked brown dorsum (Fig. 2C). Most of the males with darker dorsal surfaces were engaged in breeding activities such as egg attendance, fertilisation of eggs and male to male combat while the others were seen moving away from the breeding habitat.

\section{Call analysis}

We recorded two male advertisement calls from a single individual on 7th July 2018, the ambient temperature and humidity were $22^{\circ} \mathrm{C}$ and $93 \%$. A sharp 'krrck' call was emitted by a male at the nest site, whilst he was guarding eggs (Fig. $3)$. The mean call duration was $129 \mathrm{~ms}(128-130 \mathrm{~ms}, \mathrm{~N}=2)$, the intercall interval was $(13.8 \mathrm{~ms}, \mathrm{~N}=1)$ and the dominant frequency was $1.3 \mathrm{kHz}(\mathrm{N}=2)$ and calls had 8 pulses $(\mathrm{N}=2)$. The details of our call recordings and comparisons with the calls of congeners are given in Table 1 . We also recorded a second call type, which to the human ear was a "krrk-krrkkrrk-rrr-rrr-rrr'. These calls were continuous in nature and were emitted by several males in combat, during amplexus and while fertilising eggs. However, due to low quality of recording and continuous background noise we were unable to analyse these calls. 
Table 1. Measurements of advertisement call parameters for male Indirana sp. * denotes mean value

\begin{tabular}{|c|c|c|c|c|c|c|c|c|c|c|}
\hline & $\begin{array}{c}\text { Total } \\
\text { number } \\
\text { of calls } \\
\text { analysed }\end{array}$ & $\begin{array}{l}\text { SVL of call- } \\
\text { ing male } \\
\text { (mm) }\end{array}$ & $\begin{array}{c}\text { Call } \\
\text { duration } \\
\text { on }(m s)\end{array}$ & $\begin{array}{l}\text { Intercall } \\
\text { interval } \\
\text { (s) }\end{array}$ & $\begin{array}{l}\text { Dominant } \\
\text { frequency } \\
(\mathrm{kHz})\end{array}$ & $\begin{array}{l}\text { Pulses per } \\
\text { call }\end{array}$ & $\begin{array}{c}\text { Ambient } \\
\text { temperature } \\
\left({ }^{\circ} \mathrm{C}\right)\end{array}$ & $\begin{array}{c}\text { Ambient } \\
\text { humidity } \\
\text { (\%) }\end{array}$ & $\begin{array}{l}\text { Date of } \\
\text { recording }\end{array}$ & Reference \\
\hline I. cf. tysoni & 2 & 21 & $\begin{array}{c}129^{*} \\
(128-130)\end{array}$ & 13.8 & 1.3 & 8 & 22.0 & 93 & 7 July 2018 & This study \\
\hline 1. chiravasi & 19 & $\begin{array}{c}\text { Not } \\
\text { reported }\end{array}$ & 100 & $\begin{array}{c}\text { Not } \\
\text { reported }\end{array}$ & $\begin{array}{c}1.74^{*} \\
(1.13-3.56)\end{array}$ & $\begin{array}{l}\text { Not } \\
\text { reported }\end{array}$ & 22.5 & 94 & 12 June 2015 & Modak et al., 2016 \\
\hline $\begin{array}{l}\text { I. cf. } \\
\text { beddomii }\end{array}$ & 32 & $\begin{array}{l}\text { Not } \\
\text { reported }\end{array}$ & 109-134 & $\begin{array}{c}14.4^{*} \\
(5.5-35)\end{array}$ & $0.8-1.8$ & $\begin{array}{c}12.3^{*} \\
(10-14)\end{array}$ & 20.0 & $\begin{array}{l}\text { Not } \\
\text { reported }\end{array}$ & $\begin{array}{l}\text { June-August } \\
\text { 1995-1996 }\end{array}$ & $\begin{array}{c}\text { Kadadevaru et al., } \\
2000\end{array}$ \\
\hline I. semipalmata & 13 & 28 & 130 & $\begin{array}{l}\text { Not } \\
\text { reported }\end{array}$ & 1.6 & $\begin{array}{c}\text { Not } \\
\text { reported }\end{array}$ & 22.0 & $\begin{array}{l}\text { Not } \\
\text { reported }\end{array}$ & 30 June 1999 & $\begin{array}{c}\text { Kuramoto \& Joshy, } \\
2001\end{array}$ \\
\hline I. gundia & 27 & $\begin{array}{c}26.0^{*} \\
(23.7-30.0)\end{array}$ & $\begin{array}{c}10^{*} \\
(60-140)\end{array}$ & $\begin{array}{c}24.1^{*} \\
(3-50)\end{array}$ & 1.4 & $\begin{array}{l}6.9 *(4-10) \\
\text { at low } \\
\text { frequency }\end{array}$ & Not reported & $\begin{array}{l}\text { Not } \\
\text { reported }\end{array}$ & 26 July 1984 & $\begin{array}{l}\text { Kuramoto \& } \\
\text { Dubois, } 2009\end{array}$ \\
\hline
\end{tabular}
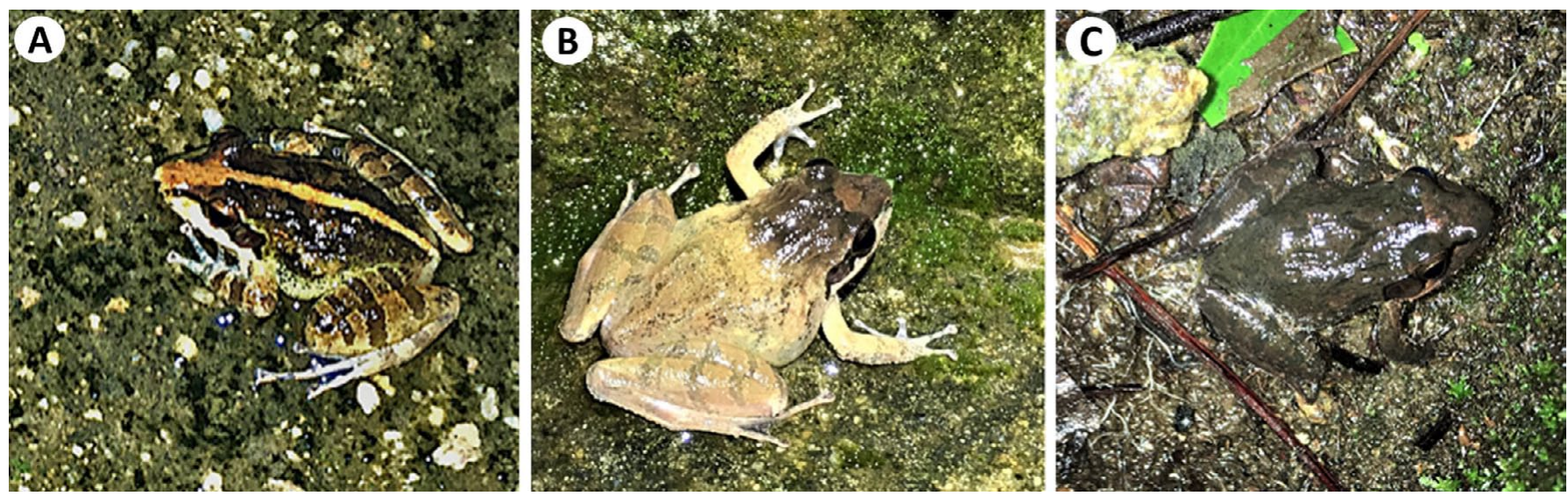

Figure 2. Dorsum colour variation in Indirana cf. tysoni males- A. Midline and snout bright ochre yellow, B. Bright yellow dorsum, and C. Dark dorsum
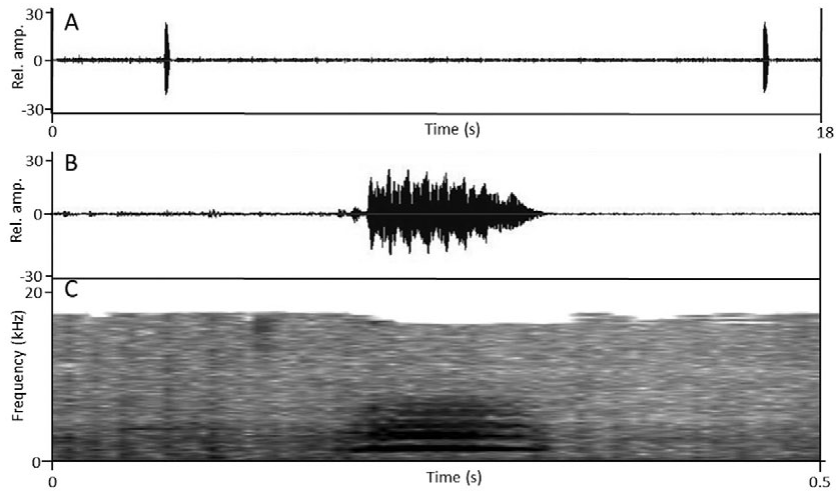

Figure 3. Advertisement call of Indirana cf. tysoni, recorded at an ambient air temperature of $22.0^{\circ} \mathrm{C}$ - A. $18 \mathrm{~s}$ waveform of relative amplitude (Rel. amp.) over time for two calls, B. $0.5 \mathrm{~s}$ waveform of relative amplitude over time for one call, and $\mathbf{C}$. $0.5 \mathrm{~s}$ spectrogram of frequency of a single call

\section{DISCUSSION}

These are the first published data on the reproductive biology of I. cf. tysoni. All the nests we observed had a water source dripping into the nest cavity as well as an outflow. This observation implies that the frogs maybe choosing nesting areas where there is an existing source of dripping water and a source of outflow on a gradient. These characteristics might ensure the maintenance of humidity, temperature and availability of water for oviposition and the subsequent development of terrestrial eggs. Nest building has been previously reported in several anuran families including Conrauidae (Schäfer et al., 2019); Dicroglossidae (Emerson, 1992); Hylidae (Lutz, 1960; Kluge, 1981) and Leptodactylidae (Heyer, 1978; Narvaes \& Rodrigues, 2005; Faggioni et al., 2017). To our knowledge, this is the first detailed report of nest building along with oviposition in the family Ranixalidae although it would appear that $I$. duboisi constructs a similar nest with water dripping into the nest site and flowing out of it (Mudke \& Thunga, 2020). Our report of male to male combat in I. cf. tysoni is also the first published report of this behaviour in a ranixalid frog. In terrestrial egg laying frogs, nests are often vigorously defended by male frogs as the construction of a nest amounts to a significant investment in time and energy (Wells, 2007), it is therefore unsurprising to find that ranixalid frogs also aggressively defend nests. Whether nesting and combat behaviours are exhibited by other ranixalid frogs is unknown.

Whilst other studies have reported multiple male Indirana present at oviposition sites (Modak et al., 2018), the subsequent gathering of males on top of the clutch immediately after it was deposited, is to our knowledge, the first published report of this behaviour in ranixalid frogs. We were unable to confirm whether eggs were fertilised by more than one male but our observation lends further support to an hypothesis that a single clutch may be fertilised by multiple males (Modak et al., 2018) and we suggest that this 
could be an intriguing area for future study. The presence of groups of males at a nest site suggest lekking (Gaitonde \& Giri, 2014) where the calls of these males may attract the female to the nest site, further observations are required to confirm this.

The most detailed published accounts of Indirana breeding behaviour and reproductive biology have not reported any form of parental care, including egg guarding (Gaitonde \& Giri, 2014; Modak et al., 2018). Egg guarding was suggested but not confirmed by one other brief report on I. cf. semipalmata (Tapley et al., 2011) where a male individual was observed in close proximity to an egg clutch on two occasions. Further study is required to ascertain whether or not males guard the eggs until hatching and time lapse photography would facilitate this. Whilst we have classified male presence as parental care, male frogs could remain at nest sites to attract other females as it is feasible that more than one clutch could be deposited within a single nest in a single breeding season.

Unlike other studies on ranixalid frogs (Kanagavel et al., 2018; Modak et al., 2018), we report two distinct call types, an advertisement call and another call emitted during male to male combat, amplexus and egg fertilisation. Our limited data preclude any inference on the function of this second call. Gaitonde \& Giri (2014) studied I. cf. beddomii and also reported two call types, an advertisement call and a more vigorous and frequent call emitted by male frogs when a female was in sight.

This work and other preliminary studies indicate that ranxialid frogs may have diverse vocal repertoires. Our study was limited by the fact that we did not have permits to collect voucher specimens or tissues for subsequent molecular analysis and so we are unable to categorically state that the frogs and tadpoles we observed were I. tysoni as frogs of the genus Indirana are morphologically conserved. Our study indicates, in the case of dorsum colour that this population of $I$. cf. tysoni is polymorphic. However, frogs in this study did conform to the published descriptions of $I$. cf. tysoni (Dahanukar et al., 2016; Garg \& Biju, 2016). Nevertheless, these observations offer a tantalising glimpse of the relatively complex behavioural repertoires that exist in this ancient lineage of frogs. Our study has wider implications in elucidating the habitat that $I$. cf. tysoni requires for breeding. Such information can lead to a better understanding of species conservation and framing of appropriate conservation action plans.

\section{ACKNOWLEDGEMENTS}

We are grateful to Dr. Gururaja KV and Dr. Aravind NA for their continuous support and timely advice, and Archit Kejriwal for overseeing the draft manuscript. We are also thankful to the reviewers for their constructive comments and feedback.

\section{REFERENCES}

ARG-UK (Amphibian and Reptile Groups of the UK) (2008). Amphibian Disease Precautions: a guide for UK fieldworkers. 1-5 pp.
BHS video (2021). Behaviour of Indirana cf. tysoni Tyson's leaping frog. https://youtu.be/DQFzMflPXSY

Brown, R.X. \& Richards, S.J. (2008). Two new frogs of the genus Platymantis (Anura: Ceratobatrachidae) from the Isabel Island group, Solomon Islands. Zootaxa 1888: 4768.

Center for Conservation Bioacoustics (2014). Raven Pro: Interactive Sound Analysis Software (Version 1.5). Ithaca, NY: The Cornell Lab of Ornithology. Available from http:// ravensoundsoftware.com/.

Cocroft, R.B. \& Ryan, M.J. (1995). Patterns of advertisement call evolution in toads and chorus frogs. Animal Behaviour 49: 283-303.

Crump, M.L. (2010). Amphibian diversity and life history. In Amphibian Ecology and Conservation, 143-166 pp. Dodd, C.K., Jr. (Ed.). New York: Oxford University Press Inc.

Dahanukar, N., Modak, N., Krutha, K., Nameer, P.O., Padhye, A.D. \& Molur, S. (2016). Leaping frogs (Anura: Ranixalidae) of the Western Ghats of India: An integrated taxonomic review. Journal of Threatened Taxa 8: 9221-9288.

Dubois, A. (1987). "1986". Miscellanea taxinomica batrachologica (I). Alytes 5: 7-95.

Duellman, W.E. (1970). The hylid frogs of middle America. Monograph of the Museum of Natural History, University of Kansas 1: 1-427.

Emerson, S.B. (1992). Courtship and nest-building behavior of a Bornean frog, Rana blythi. Copeia 1992: 1123-1127.

Faggioni, G., Souza, F., Uetanabaro, M., Landgref-Filho, P., Furman, J. \& Prado, C. (2017). Reproductive biology of the nest building vizcacheras frog Leptodactylus bufonius (Amphibia, Anura, Leptodactylidae), including a description of unusual courtship behaviour. Herpetological Journal 27(1): 73-80.

Gaitonde, N. \& Giri, V. (2014). Primitive breeding in an ancient Indian frog genus Indirana. Current Science 10(7): 109112.

Garg, S. \& Biju, S.D. (2016). Molecular and morphological study of leaping frogs (Anura, Ranixalidae) with description of two new species. PloS one, 11. e0166326. DOI: 10.1371/journal.pone.0166326

Gopalan, S. V., Nair, A., Kumar, K. S., Merilä, J. \& George, S. (2012). Morphology of Indirana semipalmata (Boulenger, 1882) (Amphibia; Anura) adults and tadpoles from the Western Ghats, India. Herpetology Notes 5: 263-273.

Gosner, K.L. (1960). A simplified table for staging anuran embryos and larvae with notes on identification. Herpetologica 16: 183-190.

Heyer, W.R. (1978). Systematics of the fuscus group of the frog genus Leptodactylus (Amphibia, Leptodactylidae). Scientific Bulletin - Natural History Museum Los Angeles County 29: 1-85.

Kadadevaru, G.G., Kanamadi, R.,D. \& Schneider, H. (2000). Advertisement call of two Indian ranids, Indirana beddomii and Tomopterna rufescens. Amphibia-Reptilia 21: 242-246.

Kanagavel, A., Parvathy, S., Chundakatil, A.P., Dahanukar, N. \& Tapley, B. (2018). Distribution and habitat associations of the Critically Endangered frog Walkerana phrynoderma (Anura: Ranixalidae), with an assessment of potential 
threats, abundance, and morphology. Phyllomedusa: Journal of Herpetology 17: 1-37.

Kluge, A.G. (1981). The life history, social organization, and parental behavior of Hyla rosenbergi Boulenger, a nest-building gladiator frog. Vol. 160. Miscellaneous Publications, Museum of Zoology, Ann Arbor, USA: University of Michigan. 170 pp.

Köhler, J., Jansen, M., Rodríguez, A., Kok, P.J.R., Toledo, L.F., Emmrich, M., Glaw, F., Haddad, C.F.B., Rödel, M.O. \& Vences, M. (2017). The use of bioacoustics in anuran taxonomy: theory, terminology, methods and recommendations for best practice. Zootaxa 4251: 1-124.

Kuramoto, M. \& Dubois, A. (2009). Bioacoustic studies on three frog species from the Western Ghats, south India. Current herpetology 28: 65-70.

Kuramoto, M. \& Joshy, H. (2001). Advertisement call structures of frogs from southwestern India, with some ecological and taxonomic notes. Current Herpetology 20: 85-95.

Kuramoto, M. \& Joshy, S.H. (2002). Tadpoles of Indirana beddomii (Anura: Ranidae). Hamadryad-madras 27: 7177.

Lutz, B. (1960). The clay nests of Hyla pardais Spix. Copeia 1960: 364-366.

Modak N., Dahanukar, N., Ogale, H. \& Padhye, A. (2016) Advertisement calls of Amboli leaping frog Indirana chiravasi (Anura: Ranixalidae) from northern Western Ghats, India. Current Science 110: 2220-2223.

Modak, N., Chunekar, H. \& Padhye, A. (2018). Life History of Western Ghats endemic and threatened Anuran Matheran leaping frog (Indirana leithii) with notes on its feeding preferences. Journal of Natural History 52: 17451761.

Mudke, M. \& Thunga, P.K. (2020). Breeding behaviour of Dubois's leaping frog Indirana duboisi (Anura: Ranixalidae). Herpetological Bulletin 152: 15-17.

Mudke, M., Gururaja, K.V., Aravind, N. \& Singal. R. (2020). Annotated list of anurans from the lateritic plateau of western India with notes on malformations. Check List 16: 685-698. DOI: 10.15560/16.3.685
Nair, A., Gopalan, S.V., George, S., Kumar, K.S., Teacher, A.G. \& Merilä, J. (2012). Endemic Indirana frogs of the Western Ghats biodiversity hotspot. In Annales Zoologici Fennici, 257-286 pp. Finnish Zoological and Botanical Publishing Board.

Narvaes, P. \& Rodrigues, M. T. (2005). Visual communication, reproductive behavior, and home range of Hylodes dactylocinus (Anura, Leptodactylidae). Phyllomedusa Journal of Herpetology 4: 147-158.

Peter, W.C. \& Reid, N.H. (2010). Egg mass and nest counts. In Amphibian Ecology and Conservation, 143-166 pp. Dodd, C.K., Jr. (Ed.). New York: Oxford University Press Inc.

Roelants, K., Jiang, J. \& Bossuyt, F. (2004). Endemic ranid (Amphibia: Anura) genera in southern mountain ranges of the Indian subcontinent represent ancient frog lineages: evidence from molecular data. Molecular Phylogenetics and Evolution 31: 730-740.

Schäfer, M., Tsekané, S.J., Tchassem, F.A.M., Drakulić, S., Kameni, M., Gonwouo, N.L. \& Rödel, M.O. (2019). Goliath frogs build nests for spawning-the reason for their gigantism? Journal of Natural History 53: 1263-1276.

Sekar, A. G. (1992). Morphometry, habitat, behaviour \& food of the tadpoles of Leith's frog Rana leithii. Journal of Bombay Natural History Society 89: 259-261.

Tapley, B.T., Purushotham, C.B. \& Girgin, S. (2011). Indirana semipalmata (brown leaping frog) reproduction. Herpetological Review 42: 87-88.

Veeranagoudar, D.K., Radder, R S., Shanbhag, B.A. \& Saidapur, S.K. (2009). Jumping behavior of semiterrestrial tadpoles of Indirana beddomii (Günther): Relative importance of tail and body size. Journal of Herpetology 43, 680684. DOI: $10.1670 / 08-158.1$

Wells, K.D. (2007). Mating Systems and Sexual Selection in Anurans. In The Ecology \& Behavior of Amphibians, 338402 pp. Chicago and London: The University of Chicago Press.

Accepted: 9 November 2020 